\author{
Paulina Krukowska-Siembida \\ Maria Curie-Skłodowska University in Lublin \\ ORCID: 0000-0002-1266-4862 \\ paulina.krukowska@umcs.pl
}

\title{
Patent Protection in the TRIPS Agreement and the Right to Health: Can They Be Reconciled?
}

\author{
Ochrona patentowa w porozumieniu TRIPS i prawo do zdrowia - \\ czy da się je ze sobą pogodzić?
}

\section{SUMMARY}

The monopoly enjoyed by pharmaceutical manufacturers, resulting from the protection of intellectual property, directly affects the price of medicinal products and thus their availability, especially in developing and least-developed countries. The aim of the article was to examine the provisions of the Agreement on Trade-Related Aspects of Intellectual Property Rights adopted under the World Trade Organization, an attempt to answer the question of whether it is possible to reconcile the protection of intellectual property with the human right to health.

Keywords: World Trade Organization; right to health; intellectual property protection; TRIPS Agreement; patent protection

\section{INTRODUCTION}

The issue of intellectual property protection has been for years a subject of lively discussion between supporters and opponents of protection. The scale of emotions is well illustrated by a quote from "The Economist" magazine issue of 26 July 1851, which stated that: "Society would soon find out that patents rarely secure really good inventions and grant ordinary trivialities the significance of a discovery, and that there would be nothing good from patent law, no matter how finely written". Opponents of intellectual property protection believe that knowledge is a public

${ }^{1}$ See A. Wróbel, Handel lekami w regulacjach Światowej Organizacji Handlu, [in:] Ochrona zdrowia w stosunkach międzynarodowych, red. W. Lizak, A.M. Solarz, Warszawa 2013, p. 78. 
good and should, therefore, not be subject to legal regulations. On the other hand, proponents of intellectual property protection point to the economic aspect, since, owing to the rights arising from the protection granted, it is profitable for companies to invest and often bear huge costs.

The conflict seems to be even more exacerbated when comparing these arguments with the issue of health rights and access to medicines. Patents undoubtedly form the basis for progress in medicine. A company which discloses a pharmaceutical formulation in the patent procedure is granted a monopoly on its production for a certain period of time. This compensates the company for the expenditure associated with the introduction of a new substance to the market. However, very often the monopoly of one company results in higher prices for medicines, which, as confirmed by World Bank analyses, makes them unavailable to poorer countries ${ }^{2}$.

In November 2001, the Committee on Economic, Social and Cultural Rights issued a statement referring to the relationship between human rights and intellectual property rights ${ }^{3}$. What the Committee particularly points out to is that the regulation of intellectual property law must be compliant with human rights and this applies both to national and international laws, including the TRIPS Agreement. The approach to intellectual property rights related to human rights requires all stakeholders to be responsible for their obligations under international human rights law, in particular with regard to the adoption, interpretation and implementation of intellectual property systems. The Committee also stresses that trade agreements are not excluded from the obligation to comply with human rights, and that specialised international organisations should seek to play a positive role in the human rights protection process.

Intellectual property rights do not operate in an empty void: not only should they serve to protect private interests, but also, and above all, they should contribute to society as a whole 4 . The main challenge in the area of intellectual property protection in the area of public health is to find a solution that would, on the one hand, safeguard the interests of manufacturers and, on the other, guarantee the safety of patients. In view of the above, pharmaceutical patents inevitably generate tension between the right of citizens to health and well-being, and the exclusivity which primarily stimulates the development of new medicines ${ }^{5}$.

2 See World Development Report 2000/2001, World Bank, Washington.

3 Human Rights and Intellectual Property Issues: Statement by the Committee on Economic, Social and Cultural Rights, 26 November 2001, ONZ E/C.12/2001/15.

4 M. Barczewski, Prawa własności intelektualnej w Światowej Organizacji Handlu a dostęp do produktów leczniczych, Warszawa 2013, p. 87.

5 M.V. Hristova, Are Intellectual Property Rights Human Rights? Patent Protection and the Right to Health, "Journal of the Patent and Trademark Office Society" 2011, Vol. 93(3), p. 339. 
This article is to analyse the Agreement on Trade-Related Aspects of Intellectual Property Rights (TRIPS) and to try to answer the question of whether it is possible to reconcile the protection of intellectual property with the human right to health.

\section{CHARACTERISTICS OF THE RIGHT TO HEALTH AND THE INTELLECTUAL PROPERTY RIGHT}

The right to health is one of the human rights enshrined in fundamental documents of universal and regional application. The first international agreement to formulate the right to health was the Constitution of the World Health Organization, adopted in $1946^{6}$. Its preamble states that: "The enjoyment of the highest attainable standard of health is one of the fundamental rights of every human being without distinction of race, religion, political belief, economic or social condition". Another document which stressed the right to medical care was the Universal Declaration of Human Rights, adopted by the United Nations General Assembly on 10 December 1948 which, in Article 25 (1), states that: "Everyone has the right to a standard of living adequate for the health and well-being of himself and of his family, including food, clothing, housing and medical care and necessary social services, and the right to security in the event of unemployment, sickness, disability, widowhood, old age or other lack of livelihood in circumstances beyond his control [...]".

The most important provision is contained in Article 12 of the International Covenant on Economic, Social and Cultural Rights ${ }^{7}$, which provides for the right of everyone to the enjoyment of the highest attainable standard of physical and mental health. Paragraph 2 lists the steps to be taken by the States Parties to achieve the full realization of this right: a) the provision for the reduction of the stillbirth-rate and of infant mortality and for the healthy development of the child; b) the improvement of all aspects of environmental and industrial hygiene; c) the prevention, treatment and control of epidemic, endemic, occupational and other diseases; d) the creation of conditions which would assure to all medical service and medical attention in the event of sickness. The Committee on Economic, Social and Cultural Rights stressed that the right to physical and mental health protection enshrined in the Covenant is not limited to the right to health care but must also be understood as the right to use a range of facilities, goods, services and conditions necessary to achieve the highest attainable standard of health, such as access to clean water, adequate sanitation and access to essential medicines ${ }^{8}$.

6 www.who.int/governance/eb/who_constitution_en.pdf [access: 10.11.2019].

www.ohchr.org/en/professionalinterest/pages/cescr.aspx [access: 10.11.2019].

8 M. Barczewski, op. cit., p. 187. 
It is no coincidence that the instruments shaping universal standards of human rights protection also contain provisions that require the protection of public and private interests in the fields of creativity and knowledge 9 . Article 27 of the Universal Declaration of Human Rights stipulates that every person has the right to the protection of the moral and material interests resulting from any scientific, literary or artistic production of which he or she is the author. This right is also reaffirmed in Article 15 (1) of the International Covenant on Economic, Social and Cultural Rights.

Although intellectual property law and human rights have largely evolved separately, the extension of the intellectual property system to the health sector requires further consideration of the growing link between the right to health and the patentability of medicines ${ }^{10}$.

\section{AGREEMENT ON TRADE-RELATED ASPECTS OF INTELLECTUAL PROPERTY RIGHTS}

The basis for patent protection is made by the Agreement on Trade-Related Aspects of Intellectual Property Rights (TRIPS) adopted as part of the World Trade Organization $^{11}$. As B. Ziemblicki writes, this agreement is not based on non-discrimination and free trade like GATT and GATS, but on the positive obligations of the parties in the form of minimum regulations and enforcement mechanisms ${ }^{12}$. Before the TRIPS Agreement entered into force, countries had the freedom to introduce and shape the patent protection adopted for their territories ${ }^{13}$. This usually resulted in many countries not patenting medicinal products. Instead, they manufactured or imported generic medicines, which are cheaper substitutes for patented products. Under the TRIPS Agreement, pursuant to Article 33, the term of protection ends with the expiration of a period of 20 years counted from the filing date ${ }^{14}$.

9 Ibidem, p. 182.

10 M.V. Hristova, op. cit., p. 340.

11 Agreement on Trade-Related Aspects of Intellectual Property Rights (as amended on 23 January 2017), www.wto.org/english/docs_e/legal_e/31bis_trips_01_e.htm [access: 12.10.2019].

12 B. Ziemblicki, Ochrona praw człowieka w systemie Ś 2013, p. 199.

13 An example of this is the Paris Convention on the Protection of Industrial Property, which has allowed the member countries to exclude entire sectors from the possibility of patenting and individually setting the length of protection of intellectual property. See S. Joseph, Blame it on the WTO? A Human Rights Critique, Oxford 2011, p. 215; M. Barczewski, op. cit., p. 13.

14 It is worth noting that the countries of the European Union, the U.S. or Japan have provided for the possibility of extending the exclusivity of the use of medicinal products after the cessation of their patent protection. As M. du Vall rightly notes, the process of placing the medicinal product on the market takes 10 years on average, so the effective patent protection period is much shorter than for 
The TRIPS preamble stresses "special needs of the least-developed country Members in respect of maximum flexibility in the domestic implementation of laws and regulations in order to enable them to create a sound and viable technological base". It is commonly pointed out in the literature that many TRIPS provisions are imprecise, thus leaving room for broad interpretation, which is referred to as "constructive ambiguity" often extremely different, positions of negotiating countries.

Very often, the rationale for patent protection is the conviction that patents are privileges granted to the inventor by society and therefore they should be subject to restrictions that take into account important social goals, such as the need to ensure access to medicines ${ }^{16}$. Article 1 of the TRIPS Agreement shows that its provisions shape the minimum protection. This means that WTO Member States may provide in their legislation for a higher level of protection than that provided for in TRIPS. As noted by J. Barcik, rigorous regulation could discourage from signing TRIPS many developing countries seeking to access such patent-protected products as pharmaceuticals ${ }^{17}$. The objectives of the TRIPS Agreement, which should be taken into account during its interpretation ${ }^{18}$, are specified in Article 7: "The protection and enforcement of intellectual property rights should contribute to the promotion of technological innovation and to the transfer and dissemination of technology, to the mutual advantage of producers and users of technological knowledge and in a manner conducive to social and economic welfare, and to a balance of rights and obligations". The principles of the TRIPS Agreement are set out in Article 8: "1. Members may, in formulating or amending their laws and regulations, adopt measures necessary to protect public health and nutrition, and to promote the public interest in sectors of vital importance to their socio-economic and technological development, provided that such measures are consistent with the provisions of this Agreement; 2. Appropriate measures, provided that they are consistent with the provisions of this Agreement, may be needed to prevent the abuse of intellectual property rights by right holders or the resort to practices which unreasonably restrain trade or adversely affect the international transfer of

other inventions. See M. du Vall, [in:] System Prawa Prywatnego, t. 14A: Prawo własności przemystowej, red. R. Skubisz, Warszawa 2012, pp. 136-137. In the WTO-held dispute between the European Communities and Canada on the protection of patent pharmaceutical products, it was assumed that the actual duration of the patent is between 8 and 12 years. See WT/DS114/R, paragraph 7.3.

${ }_{15}$ M. Barczewski, op. cit., p. 73.

16 C.M. Ho, Access to Medicine on the Global Economy: International Agreements on Patents and Related Rights, Oxford 2011, p. 159.

17 J. Barcik, Międzynarodowe prawo zdrowia publicznego, Warszawa 2013, p. 31.

18 Article 31 (1) of the Vienna Convention on the law of treaties states that "A treaty shall be interpreted in good faith in accordance with the ordinary meaning to be given to the terms of the treaty in their context and in the light of its object and purpose". 
technology". Therefore, the TRIPS Agreement strives to find a balance between the long-term goal of stimulating research into new inventions and the short-term goal of enabling people to use existing ones ${ }^{19}$.

Furthermore, the TRIPS Agreement provides for certain exceptions to patentability once certain strict conditions are met. These include voluntary licensing, compulsory licensing and the so-called Bolar amendment. Article 27 (2) allows members to exclude from patentability inventions, the prevention within their territory of the commercial exploitation of which is necessary to protect ordre public or morality, including to protect human, animal or plant life or health or to avoid serious prejudice to the environment. The condition for such an exclusion is that it is not made merely because the exploitation is prohibited by their law. Voluntary licenses allow the production of generic drugs in accordance with patent law. Pursuant to Article 28 of the TRIPS Agreement, "Patent owners shall also have the right to assign, or transfer by succession, the patent and to conclude licensing contracts". It is worth pointing out, however, that the granting of a voluntary license depends solely on the goodwill of the patent owner.

On the other hand, Articles 30 and 31 of the TRIPS Agreement govern the possibility of excluding rights that are already protected by a patent. The first of them states that Members may provide limited exceptions to the exclusive rights conferred by a patent, provided that such exceptions do not unreasonably conflict with a normal exploitation of the patent and do not unreasonably prejudice the legitimate interests of the patent owner, taking account of the legitimate interests of third parties. The literature underlines that this is a special case, the purpose of which is to encourage the undertakings to manufacture substitute products. Where medicines are protected by patents, countries may lay down rules that allow, for example, the launch of tests and the adoption of decisions to allow substitutes even before the end of the protection period of the medicine concerned ${ }^{20}$. This provision is often called the regulatory provision or the Bolar provision and has been maintained as compatible with the TRIPS in the WTO Panel's decision of 17 March 2000 on the assessment of the legality of the Canadian version of the Bolar exception ${ }^{21}$, which

19 WTO Agreements \& Public Health. A joint study by the WHO and the WTO Secretariat, WHO, WTO, 2002, p. 39.

${ }^{20}$ B. Ziemblicki, op. cit., p. 201.

${ }^{21}$ Roche Products, Inc. owned a patent for the active substance flurazepam with psychotropic properties, constituting a component of a drug for the treatment of insomnia, Dalmane. One year before the patent expiry, pharmaceutical company Bolar Pharmaceutical Col., Inc. began working to be able to manufacture this drug once the patent expires. Roche then accused Bolar of infringing the Roche's patent right on the grounds that Bolar had conducted experimental research on the active substance of the patented drug. See Canada - patent protection of pharmaceutical products. Complaint by the European Communities and their Member States. Report of the Panel, WTO, Geneva 17.03.2000, WT/DS114/R. 
allows medicinal product manufacturers to use a protected active substance for the purpose of carrying out the registration procedure of the medicine concerned and obtaining during the term of patent protection a marketing authorisation once the patent is discontinued ${ }^{22}$.

Article 31 of the TRIPS Agreement goes even further by introducing compulsory licences, granted without the consent of the patent owner. Where the national legislation allows for other uses of the subject matter of a patent without the authorisation of the patent right holder, such use will be permitted provided that prior efforts have been made to obtain authorisation from the right holder on reasonable commercial terms and conditions and that such efforts have not turned out to be successful within a reasonable period of time. Exceptionally, a Member State may waive this requirement in the case of a national emergency or other circumstances of extreme urgency or in cases of public non-commercial use. J. Barcik notes that the use of the expression "within a reasonable period of time" in this provision is highly vague, offering pharmaceutical corporations a lot of room for negotiation with the governments of developing countries ${ }^{23}$. At the same time, Article 31 of the TRIPS Agreement lays down several conditions that must be met cumulatively to consider such use lawful, including assessment of the legitimacy of the use based on individual merits of the case, a prior attempt to obtain authorisation from the right holder, the payment of adequate remuneration to the right holder, and the non-exclusivity and non-assignability of the use ${ }^{24}$.

\section{ACTIONS TO IMPROVE ACCESS TO MEDICINES IN THE DOHA ROUND}

It is very often argued by scholars in the field that patent protection in its current form is contrary to the right to health ${ }^{25}$. The WTO itself is attempting to improve this situation by amending existing regulations in order to make them more aimed at meeting public health needs.

On 9-13 November 2001, a Ministerial Conference took place in the capital of Qatar, Doha, during which the first round of multilateral trade negotiations at the forum of the World Trade Organisation started. The Ministerial Declaration pointed out that the main objective of the negotiation was to develop international trade

22 A. Sztoldman, Korzystanie z chronionego wynalazku w celu rejestracji produktu leczniczego, Warszawa 2018, p. $26 \mathrm{ff}$.

${ }^{23}$ J. Barcik, op. cit., p. 32.

${ }^{24}$ B. Ziemblicki, op. cit., p. 201.

${ }_{25}$ See P. Cullet, Patents Bill, TRIPS and right to health, "Economic and Political Weekly" 2001, October 27, pp. 4029-4051; C. Feng-Wu, Raising the right to health concerns within the framework of international intellectual property law, "Asian Journal of WTO \& International Health Law and Policy" 2010, Vol. 5, pp. 141-205. 
rules that take greater account than before of the interests of developing countries, thereby allowing for a wider integration of this group of countries into the WTO multilateral trade system ${ }^{26}$.

The particular importance of public health issues in the Doha Development Round was underlined by the separate Declaration on the TRIPS Agreement and Public Health. During the meeting of the TRIPS Council held in April 2001, the Zimbabwean representatives highlighted the problem of access to low-cost medicines and the lack of clear guidelines on how to interpret and apply TRIPS provisions. In June 2001, another meeting of the TRIPS Council was held, which, as emphasized by K. Gamharter, was the first meeting in an international trade forum to formally address the discussion on access to medicinal products ${ }^{27}$.

On 14 November 2001, during the fourth WTO Ministerial Conference, the text of the Declaration on the TRIPS Agreement and Public Health (the Doha Declaration $)^{28}$ was adopted unanimously. Paragraph 1 thereof underlines that the parties "recognize the gravity of the public health problems afflicting many developing and least-developed countries, especially those resulting from HIV/AIDS, tuberculosis, malaria and other epidemics". The declaration confirms "the need for the WTO Agreement on Trade-Related Aspects of Intellectual Property Rights (TRIPS Agreement) to be part of the wider national and international action to address these problems" (paragraph 2) and "recognize that intellectual property protection is important for the development of new medicines" (paragraph 3). Therefore, WTO members, while maintaining their obligations under the TRIPS Agreement, have the right to: a) apply customary rules of interpretation to TRIPS; b) independently grant compulsory licenses and set out the rules for granting them; c) determine emergency situations independently, while HIV/AIDS, malaria or tuberculosis can represent such situations; d) independently determine the rules for exhaustion of patentability of products ${ }^{29}$. Finally, WTO members confirmed the commitment of developed countries to promoting and supporting technology transfer to the poorest countries. One should agree with B. Ziemblicki that the declaration shows not only the WTO's awareness of the problem of the relationship between intellectual property law and human rights, but also particular possible solutions and difficulties in their implementation ${ }^{30}$.

The Declaration on the TRIPS Agreement and Public Health became the point of departure for further actions of the TRIPS Council to find a solution to the prob-

${ }^{26}$ M. Grącik-Zajączkowska, Unia Europejska i Stany Zjednoczone w Światowej Organizacji Handlu, Warszawa 2010, pp. 243-245.

${ }^{27} \mathrm{~K}$. Gamharter, Access to Affordable Medicines: Developing Responses under the TRIPS Agreement and EC Law, Berlin-Heidelberg 2004, p. 125.

${ }^{28}$ WTO, Declaration on the TRIPS Agreement and Public Health, WT/MIN(01)/DEC/2.

${ }^{29}$ Ibidem, $\S 5$.

${ }^{30}$ B. Ziemblicki, op. cit., p. 205. 
lem of compulsory licenses ${ }^{31}$. The system was built in two stages. First, in 2003, the WTO General Council issued a decision on the implementation of paragraph 6 of the Doha Declaration ${ }^{32}$. This decision, also known as "the waiver decision" 33 , provided for a waiver of the obligation to comply with Article 31 (f) the TRIPS Agreement, which allows authorisation to use the subject matter of a patent without the consent of the right holder only if issued for the purpose of supplying the internal market of a Member State.

The second decision was adopted by the WTO General Council on 6 December 2005 and submitted to the members for approval ${ }^{34}$. The protocol is an amendment to the TRIPS Agreement. This is the first multilateral treaty amendment agreed by WTO members since the entry into force of the WTO Agreement in 1995. The purpose of this regulation is to permanently incorporate in the TRIPS Agreement additional possibilities to grant compulsory licenses for the export of medicines. As a result, a company who is not the owner of a patent will be able to manufacture and sell substitutes of medicines covered by patent protection where a situation of a threat to public health occurs in an importing country.

The system became a permanent part of the Agreement on 23 January 2017, following the acceptance of the Protocol by two-thirds of the members ${ }^{35}$. So far, the mechanism established under the WTO Decision of 30 August 2003 and the Protocol to the TRIPS Agreement was used only once in 2007 by the Canadian company Apotex, the entity responsible for patents for the production of the generic drug TriAvir used in the treatment of AIDS. The company has agreed to supply to Rwanda a total of 260,000 packages at the production price.

One should point to yet another problem with the protection of intellectual property, namely, as statistics show, research in the pharmaceutical sector mainly involves diseases the treatment of which gives the greatest profits, i.e. diseases most occurring in rich countries ${ }^{36}$. This means that in the event of certain diseases,

31 A. Wróbel, op. cit., p. 86.

${ }^{32}$ Implementation of paragraph 6 of the Doha Declaration on the TRIPS Agreement and public health, Decision of the General Council of 30 August 2003, General Council, WT/L/540 and Corr. 1, www.wto.org/english/tratop_e/trips_e/implem_para6_e.htm [access: 23.10.2019].

33 J. Barcik, op. cit., p. 35.

34 Amendment of the TRIPS Agreement, 6 December 2005. The amendment consists in inserting Article 31 bis following Article 31.

35 According to the WTO Agreement, a Member formally accepts the Protocol by depositing what is referred to as an instrument of acceptance for the Protocol with the Director General of the WTO. Members who have not yet done so, may accept the Protocol until 31 December 2019 or such later date as may be decided by the Ministerial Conference. See: How to accept the Protocol Amending the TRIPS Agreement. Background information for Members on procedures, www.wto.org/english/ tratop_e/trips_e/accept_e.htm [access: 12.10.2019].

${ }^{36}$ According to the Commission of Intellectual Property Rights, less than 5\% of the total money allocated globally to research and development of new drugs is spent on diseases affecting developing 
other incentives for innovation should be sought than the possibility of patenting a drug $^{37}$. In response, T. Pogge proposed an alternative programme of encouraging pharmaceutical research, involving countries that would contribute to the Health Impact Fund from which inventors of new pharmaceuticals are to be paid ${ }^{38}$.

\section{CONCLUSION}

Despite the fact that the TRIPS Agreement seems to guarantee great flexibility, many of the issues arising from its provisions raise controversy. The TRIPS Agreement in its current form prevents poor countries from buying the best medicines. Is it possible to reconcile the interests of companies with the right of people, especially the poorest, to health?

J. Tobin points out that the right to health should be used as a tool for interpretation of the TRIPS Agreement. Consequently, where an unresolvable normative conflict arises, it is necessary to ensure that any interference of the protection of intellectual property into the right of access to medicinal products is justified, necessary and proportionate ${ }^{39}$. In addition, there are flexible and adaptive measures under the TRIPS Agreement itself, such as compulsory licences to be used by the WTO Member States to increase access to medicinal products ${ }^{40}$.

The High Commissioner's Report presents an example of the use of authorised strategies in the fight against HIV/AIDS by the Brazilian government between 1997 and $2001^{41}$. The Ministry of Health of Brazil developed a treatment consisting of twelve different pharmaceuticals, seven of which were produced in Brazil and the remaining five were imported. Two of these five imported were protected with patents in Brazil. The purchase of two patented drugs consumed $36 \%$ of the price of all the twelve drugs. For this reason, the Brazilian government was looking for methods to encourage the international pharmaceutical industry to enter into negotiations on drug sales, considering the purchasing power of the market. The introduction of compulsory licence provisions allowed Brazil to obtain favourable conditions for the purchase of medicines and thus increase the availability of HIV/

countries. For more details, see P. Ranjan, Understanding the Conflicts between the TRIPS Agreement and the Humam Right to Health, "Journal of World Investment \& Trade" 2008, Vol. 9(6), DOI: https:// doi.org/10.1163/221190008X00278, pp. 551-570.

37 B. Ziemblicki, op. cit., p. 204.

${ }^{38}$ S. Joseph, op. cit., p. 240.

${ }^{39}$ M. Barczewski, op. cit., p. 204.

${ }^{40}$ See also H. Hestermeyer, Human Rights and the WTO. The Case of Patents and Access to Medicines, Oxford 2007.

${ }^{41}$ Report of High Commissioner "The impact of the Agreement on Trade-Related Aspects of Intellectual Property Rights on Human Rights", E/CN.4/Sub.2/2001/12. 
AIDS drugs. Brazil's example shows that the TRIPS Agreement gives states the instruments to effectively struggle for the health of their citizens. Nonetheless, these measures play only a supportive role and do not constitute a panacea for the challenges faced by global access to medicines.

\section{REFERENCES}

Agreement on Trade-Related Aspects of Intellectual Property Rights (as amended on 23 January 2017), www.wto.org/english/docs_e/legal_e/31bis_trips_01_e.htm [access: 12.10.2019].

Barcik J., Międzynarodowe prawo zdrowia publicznego, Warszawa 2013.

Barczewski M., Prawa wtasności intelektualnej w Światowej Organizacji Handlu a dostęp do produktów leczniczych, Warszawa 2013.

Canada - patent protection of pharmaceutical products. Complaint by the European Communities and their Member States. Report of the Panel, WTO, Geneva 17.03.2000, WT/DS114/R.

Constitution of the World Health Organization, adopted in 1946, www.who.int/governance/eb/who constitution_en.pdf [access: 10.11.2019].

Cullet P., Patents Bill, TRIPS and right to health, "Economic and Political Weekly" 2001, October 27.

Feng-Wu C., Raising the right to health concerns within the framework of international intellectual property law, "Asian Journal of WTO \& International Health Law and Policy” 2010, Vol. 5.

Gamharter K., Access to Affordable Medicines: Developing Responses under the TRIPS Agreement and EC Law, Berlin-Heidelberg 2004.

Grącik-Zajączkowska M., Unia Europejska i Stany Zjednoczone w Światowej Organizacji Handlu, Warszawa 2010.

Hestermeyer H., Human Rights and the WTO. The Case of Patents and Access to Medicines, Oxford 2007.

Ho C.M., Access to Medicine on the Global Economy: International Agreements on Patents and Related Rights, Oxford 2011.

How to accept the Protocol Amending the TRIPS Agreement. Background information for Members on procedures, www.wto.org/english/tratop_e/trips_e/accept_e.htm [access: 12.10.2019].

Hristova M.V., Are Intellectual Property Rights Human Rights? Patent Protection and the Right to Health, "Journal of the Patent and Trademark Office Society" 2011, Vol. 93(3).

Human Rights and Intellectual Property Issues: Statement by the Committee on Economic, Social and Cultural Rights, 26 November 2001, ONZ E/C.12/2001/15.

Implementation of paragraph 6 of the Doha Declaration on the TRIPS Agreement and public health, Decision of the General Council of 30 August 2003, General Council, WT/L/540 and Corr. 1, www.wto.org/english/tratop_e/trips_e/implem_para6_e.htm [access: 23.10.2019].

International Covenant on Economic, Social and Cultural Rights, adopted and opened for signature, ratification and accession by General Assembly resolution 2200A (XXI) of 16 December 1966 entry into force 3 January 1976, in accordance with Article 27, www.ohchr.org/en/professionalinterest/pages/cescr.aspx [access: 10.11.2019].

Joseph S., Blame it on the WTO? A Human Rights Critique, Oxford 2011.

Ranjan P., Understanding the Conflicts between the TRIPS Agreement and the Humam Right to Health, "Journal of World Investment \& Trade" 2008, Vol. 9(6),

DOI: https://doi.org/10.1163/221190008X00278.

Report of High Commissioner "The impact of the Agreement on Trade-Related Aspects of Intellectual Property Rights on Human Rights", E/CN.4/Sub.2/2001/12. 
Pobrane z czasopisma Studia Iuridica Lublinensia http://studiaiuridica.umes.pl Data: 26/04/2023 10:46:03

Sztoldman A., Korzystanie z chronionego wynalazku w celu rejestracji produktu leczniczego, Warszawa 2018.

Vall M. du, [in:] System Prawa Prywatnego, t. 14A: Prawo własności przemysłowej, red. R. Skubisz, Warszawa 2012.

World Development Report 2000/2001, World Bank, Washington.

Wróbel A., Handel lekami w regulacjach Światowej Organizacji Handlu, [in:] Ochrona zdrowia w stosunkach międzynarodowych, red. W. Lizak, A.M. Solarz, Warszawa 2013.

WTO Agreements \& Public Health. A joint study by the WHO and the WTO Secretariat, WHO, WTO, 2002.

WTO, Declaration on the TRIPS Agreement and Public Health, WT/MIN(01)/DEC/2.

Ziemblicki B., Ochrona praw człowieka w systemie Światowej Organizacji Handlu, Toruń 2013.

\section{STRESZCZENIE}

Monopol przysługujący producentom leków, wynikający z ochrony własności intelektualnej, wpływa bezpośrednio na cenę produktów leczniczych, a co za tym idzie na ich dostępność, szczególnie w krajach rozwijających się i najmniej rozwiniętych. Celem artykułu była analiza postanowień porozumienia w sprawie handlowych aspektów praw własności intelektualnej, przyjętego w ramach Światowej Organizacji Handlu, a także próba odpowiedzi na pytanie, czy możliwe jest pogodzenie ochrony własności intelektualnej z prawem człowieka do zdrowia.

Słowa kluczowe: Światowa Organizacja Handlu; prawo do zdrowia; ochrona własności intelektualnej; porozumienie TRIPS; ochrona patentowa 